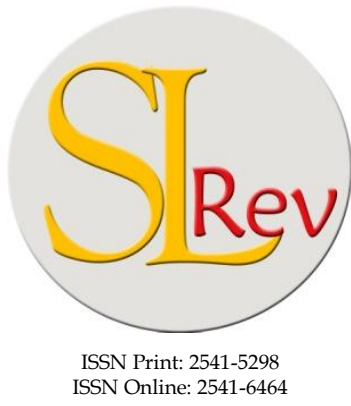

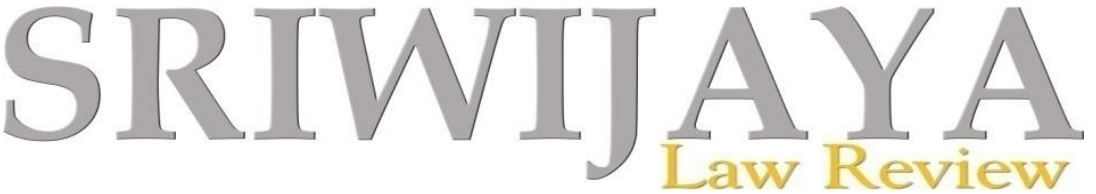

Editorial Office: Faculty of Law, Sriwijaya UniversityJalan Srijaya Negara, Palembang, South Sumatra 30139, Indonesia. Phone: +62711-580063Fax: +62711-581179

E-mail: sriwijayalawreview@unsri.ac.id|sriwijayalawreview@gmail.com Website: http://journal.fh.unsri.ac.id/index.php/sriwijayalawreview

\title{
Legal Perspective of Using Philanthropy Approach for Low Income Household in Accessing Sufficient House in Indonesia
}

\author{
Efridani Lubis ${ }^{*}$ and Astriana Sinaga ${ }^{* *}$
}

\begin{abstract}
By 2016, the backlog for housing is estimated around 13,8 million units. With the need growth 5\% per year approximately, Indonesian people need 1 million houses per year. Adding to the number of backlog, it is around 1,55 million houses should be provided every year in order to meet the need in the year 2030. The number is based on the ability to pay in general of Indonesian people, which is with the price for sufficient house estimated to be 135 million rupiahs. This means low income household is out of consideration, therefore this group cannot afford the house whatsoever. In order to narrower the gap, the Government of Indonesia has built 'One Million Houses Program' which has composition $70 \%$ for low income household. However, the program has not optimal yet. From the data from the Public Work and Housing Ministry, it is only $80 \%$ of the 1 million houses targeted that can be achieved; and from this $80 \%$, only 569.382 units or $70,72 \%$ for the low income household. With this trend, it is difficult for the low income household to access sufficient houses in turn. The solution for this can be two alternatives: (1) the Government provide affordable houses for the group, or (2) increasing the ability to pay of the group. The alternative (1) could be difficult due to the limited budget of the Government. The possible answer is to increase the ability of the low income households, so that they can access houses either under subsides scheme from the Government or developers. In doing so, the main problem is to collect or acquire the funding for accessing the house. Using various regulations and policies that could make possible for low income households to receive the money, such as corporate social responsibility, zakat, or even philanthropy activities in Indonesia, the burden could be lessen. The importance of giving the low income households opportunity to access sufficient house is a notion that a sufficient housing can be a strategic toll for improving citizen life which becomes a background argument in the Law No. 1 of 2011 of Housing.
\end{abstract}

Keywords: philanthropy; housing; low income household.

\section{ARTICLE HISTORY :}

\section{DOI: 10.28946/slrev.Vol2.Iss1.113.pp93-109}

Received: Apr 11, 2017;

Reviewed: May 10, 2017;

Accepted: July 10, 2017;

Published: Jan 31, 2018;

Citation: V.2.1 SLRev. 2018.

* Universitas Islam As-Syafi'iyah E-mail: efridani@yahoo.com

** Universitas Muhammadiyah Jakarta E-mail:astri01@yahoo.com

\section{INTRODUCTION}

Sustainable Development Goals of United Nation that directed all nations should hand in hand to growth that no one left behind until 2030 makes every and each nation more focus to fulfil SDG goals and programs. Among those goals and programs is housing. Housing is considered as an important element in SDG due to its 
essential role in developing a human being.

In the constitutional level, the role of government to provide a housing has been pointed in Article $28 \mathrm{H}$ that stated every citizen have a right to live prosperously, have a decent and sufficient housing with good and health environment and also to have medical services. According to this article, it is a right of the citizen to have a sufficient housing; since it is a right, the State is obliged to fulfil this right.

It is understood that providing a sufficient housing for all citizen needs a huge budget. Therefore, the focus of the State or Government obligation mentioned is low income household that assumed do not have ability to buy a sufficient house for themselves rather they need a support and help from other party, especially the Government. On the other hand, the Government also has a limited budget so that private sector or society in large is invited to contribute to solve some of the society's issues. One scheme of this private sector's involvement is known as corporate social responsibility or CSR.

The emerging of corporate social responsibility (CSR) trigged by the awareness and the concerned of lots of state leaders in 1960's for environmental degradation due to excessive pesticide usage which was harmful to the ecosystem as Carson pointed out in her book 'Silent Spring' where there are no birds' singing anymore in spring time because most of them has been killed by pesticide. Since then, the concept of attaching environment issue to business activity has been discussed and developed and became more important in the 1990's when Earth Summit decided that business has to take a part and responsibility to promote sustainable development and implemented principles recommended in their daily practices.

However, the concept of attaching business to its environment in larger idea has already been introduced by Frank Abrams, chairman of the board for Standard Oil of New Jersey in 1951. He wrote in Harvard Business Review that corporate was obliged to conduct affairs of the enterprise to maintain an equitable and workable balance among the claims of the various directly interested groups, a harmonious balance among stockholders, employees, customers, and the public at large. ${ }^{1}$

The basic principle of introducing CSR in community is ethical element of business. In general, business is always considered as an activity to gain more and more profit merely without or limited consideration of other impacts in doing such business. As awareness of environmental balancing is increasing; all elements of human activity must be assured not to harm their environment in order to preserve good and health habitation, including business practice. Therefore, it needs argumentation, procedure, and task force to implement such idea which is accommodated in CSR.

The problem in the concept is not about why the concept is necessary, but concerning how the contribution of business practitioners should be measured and in what form. Since there is no single

\footnotetext{
${ }^{1}$ Frederick, W. 2006. Corporation, Be Good! The Story of Corporate Social Responsibility. Indianapolis: Dog Ear Publishing.
} 
guideline how to implement this idea, from the practice we can see the broad sense and interpretation to this idea. In the ancient time, the contribution could be in a form of money to fund military campaign, financial donation for charity, promote human rights, education, health and safety, or community development. The idea of implementing CSR today is to make a meaningful contribution to the betterment of the local community and the larger society in which the business operates.

In order to provide a guideline of CSR implementation that ensure in line with its objective, many rules, guideline, standard procedures even regulations have been arranged. One of the ideas is ISO 26000. According to this standard, social responsibility concerns the behavior of an organization with respect to its impact on others and on the natural environment. As with the broader concept of responsibility, the social responsibility of corporate involves being held accountable for action and decision. Since the action and decision involves willingness of the corporate, it is an intrinsically moral or ethical concept requiring in order to determine right or wrong. The social responsibility actions constitute the decision to refrain from a specific activity where that is considered the right thing to do. The range of the actions could cover understanding the impacts of the corporate on others, including the identification of those impacted by corporate activities, measuring and reporting of impact and the related aspect of the corporate performance, engagement of those impacted, until changes in behavior that are made to increase the beneficial effects of the corporate activities for society.

In national level, Indonesia has been amended corporate regulation in 2007 through Law Number 40 Year 2007. According to this law, every business that used and/or related to natural resources in its business obliges to conduct social and environmental responsibilities. The reason to this approach is to keep harmonious and balances between corporation and its environment comply with local society's value, norm, and culture.

Keeping harmony and balance of corporate activity and its environment in order to achieve a better quality of life is a very broad notion that could be interpreted from certain and specific purpose. To make sure that CSR become effective and make a significant contribution to local community and environment, it needs to develop further and accommodate temporary and permanent needs of these local community and environment. Perhaps, one of the temporary needs is promoting access to housing system for poor people to enhance their quality of life in turn.

\section{METHOD}

Housing as a key element of human welfare has driven the Government all over the world to make a policy of providing affordable and yet sufficient house for the citizen. On the other hand, housing is also considered as promising and potential business. The two crosswise put the house on the stake depends on which side stronger to pull it. One of the congruent approaches suggests that the Government make a policy of providing houses integrated with business concern. To do so, 
the role of the government mainly provides subsidies for low income households to enable them accessing the sufficient house. However, the ability of providing the fund is very limited. The other alternative opens through maximizing regulations that make possible of rich people to share their fortune into society.

Using all related regulations to the philanthropic activities in Indonesia, the focus of this study is possibility to draw mechanism of subsidizes low income households in accessing house for their family in order to increase their standard of living and their welfare eventually.

Based on the research objective, this study uses a qualitative research. According to Creswell (1994:6), the qualitative method as an inquiry process of understanding a social or human problem, based on building a complex, holistic picture, forms with words, reporting detailed view of information, and conducted in a natural setting. Similar definition comes from Bogdan and Biklen (1982:5) which define qualitative method as a procedure resulted descriptive data such as written or verbal explanation of people and observed behaviors.

The data used in this study primarily from gathering related regulations combined with various literatures. The combination of the two will be analyzed further in order extracting the propose result to the issue.

\section{Research Framework}

Philanthropy in terminology term is philein which means love and anthropos which means human being, philanthropy then the action of loving human being based on humanity therefore he/she willingly giving his/her time, money, and labors to help others. According to Oxford dictionary, philanthropy means the desire to promote the welfare of others, expressed especially by the generous donation of money to good causes. By definition, the essence of the philanthropy is based on voluntary action not obligation and the goal of its activity is basic human needs that related closely to the qualification of descent human life.

The idea of philanthropy in Indonesia has been accommodated and becomes a legal umbrella at the same time since the Indonesian constitution, UUD 1945 specifically in Article 34 stipulates that the State should protect poor people and abandon children, developing social security system, and also empowering the marginal society into civilized society. The State also is obliged to provide medical and sufficient public services facilities. This means that the State up to some degree plays a role as philanthropist. However, the ability of the State to fulfill such needs is limited, so that all parties that would like to participate in this area will be very helpful. This is a chance for philanthropist in general to be involved systematically for better Indonesian people life. In this sense, it is necessary that the State makes a mapping and blue print how to optimized the resource of philanthropy very carefully in order to fulfill the Article 34 UUD 1945 mentioned above.

One of the efforts of the Government of Indonesia is providing related regulation to invite philanthropist participation. According to the Study of Atmajaya University team (Yusmik, 
2017) there are no less than 21 regulations in this issues, but most of them do not comply with the notion of philanthropy itself, rather the approach is basically as an obligation for certain parties to help the Government to fulfill its obligation in certain area. For the purpose of this article, I would like to focus on 8 regulations randomly to give a picture how philanthropy actions have been planned in Indonesia.

Table 1: Mapping Philanthropy Issue in Chosen Regulations in Indonesia

\begin{tabular}{|c|c|c|c|}
\hline No & Regulations & Philanthropy Aspects & Target \\
\hline \multirow[t]{2}{*}{1} & \multirow{2}{*}{$\begin{array}{l}\text { Law No. } 1 \text { of } \\
2011 \text { regarding } \\
\text { Housing and } \\
\text { Residential } \\
\text { Management }\end{array}$} & $\begin{array}{l}\text { The government should provide the housing for } \\
\text { low income household through providing the as- } \\
\text { sistances and/or facilities }\end{array}$ & \multirow[t]{2}{*}{$\begin{array}{l}\text { Developers for } \\
\text { low income } \\
\text { household }\end{array}$} \\
\hline & & $\begin{array}{l}\text { Developers should provide balanced housing } \\
\text { when they build houses; the balanced with } \\
\text { scheme: } 1 \text { luxury house for } 2 \text { modest houses and } 3 \\
\text { simple but sufficient houses for low income } \\
\text { household in the same environment }\end{array}$ & \\
\hline \multirow[t]{2}{*}{2} & \multirow[t]{2}{*}{$\begin{array}{l}\text { Law No. } 20 \text { of } \\
2011 \text { regarding } \\
\text { Apartment }\end{array}$} & $\begin{array}{l}\text { The Government have a responsible to construct } \\
\text { public apartment which could receive assistances } \\
\text { and facilities from the Government. }\end{array}$ & \multirow[t]{2}{*}{$\begin{array}{l}\text { Developers for } \\
\text { low income } \\
\text { household }\end{array}$} \\
\hline & & $\begin{array}{l}\text { Developers of commercial apartment should pro- } \\
\text { vide public apartment at least } 20 \% \text { of total con- } \\
\text { structed commercial apartment's wide floor }\end{array}$ & \\
\hline \multirow[t]{2}{*}{3} & \multirow{2}{*}{$\begin{array}{l}\text { Law No. } 13 \text { of } \\
2011 \text { regarding } \\
\text { Poor House- } \\
\text { hold Manage- } \\
\text { ment }\end{array}$} & $\begin{array}{l}\text { The Government should make a program of han- } \\
\text { dling the poor in the manner of focus, sustainable, } \\
\text { and comprehensively and provide an assistance } \\
\text { related to sufficient foods and clothes }\end{array}$ & \multirow[t]{2}{*}{$\begin{array}{l}\text { Government and } \\
\text { business people } \\
\text { for the poor }\end{array}$} \\
\hline & & $\begin{array}{l}\text { Business people could be participated in the form } \\
\text { of funding for society's development as the mani- } \\
\text { festation of their social responsibility }\end{array}$ & \\
\hline \multirow[t]{3}{*}{4} & \multirow{3}{*}{$\begin{array}{l}\text { Law No. } 23 \text { of } \\
2011 \text { regarding } \\
\text { Zakat }\end{array}$} & $\begin{array}{l}\text { Badan Amil Zakat Nasional or BAZNAS is an } \\
\text { organization of zakat management nationally. }\end{array}$ & \multirow{3}{*}{$\begin{array}{l}\text { Muzakki for } \\
\text { mustahik on } \\
\text { voluntary based. }\end{array}$} \\
\hline & & $\begin{array}{l}\text { The term and condition of accounting zakat is } \\
\text { referred to Islamic syari'a and done by muzakki } \\
\text { or the person whom paying zakat }\end{array}$ & \\
\hline & & $\begin{array}{l}\text { The distribution of zakat to mustahik (person who } \\
\text { has a right to receive zakat) should comply with } \\
\text { Islamic syari'a under priority scale that opened to } \\
\text { funding productive business in the sense of in- } \\
\text { creasing the life of the poor and quality of the } \\
\text { ummah after the basic needs of the mustahik has } \\
\text { been fulfilled }\end{array}$ & \\
\hline \multirow[t]{2}{*}{5} & \multirow{2}{*}{$\begin{array}{l}\text { Law No. } 40 \text { of } \\
2007 \text { regarding } \\
\text { Limited Cor- } \\
\text { poration jo. } \\
\text { Government } \\
\text { Regulation No. } \\
47 \text { of } 2012 \\
\text { regarding Cor- } \\
\text { porate Social } \\
\text { and Environ- } \\
\text { ment Respon- } \\
\text { sibility }\end{array}$} & $\begin{array}{l}\text { Corporates has social and environmental respon- } \\
\text { sibility when they used natural resources in their } \\
\text { businesses' activities }\end{array}$ & \multirow[t]{2}{*}{$\begin{array}{l}\text { Corporate for } \\
\text { environment } \\
\text { and/or social }\end{array}$} \\
\hline & & $\begin{array}{l}\text { The expense of fulfilling such corporates respon- } \\
\text { sibility should be included in the corporates' ex- } \\
\text { penses which should take an element of appropri- } \\
\text { ateness and fairness into consideration }\end{array}$ & \\
\hline
\end{tabular}




\begin{tabular}{|c|c|c|c|}
\hline \multirow[t]{3}{*}{6} & \multirow{3}{*}{$\begin{array}{l}\text { Law No. } 40 \text { of } \\
2004 \text { regarding } \\
\text { National So- } \\
\text { cial Security } \\
\text { System }\end{array}$} & $\begin{array}{l}\text { Employers should register themselves and their } \\
\text { employees as a member of national social security } \\
\text { system according to their followed program with } \\
\text { portion as stipulated }\end{array}$ & \multirow{3}{*}{$\begin{array}{l}\text { - } \text { Government } \\
\text { for } \\
\text { unemployees } \\
\text { - Employers } \\
\text { for } \\
\text { employees }\end{array}$} \\
\hline & & $\begin{array}{l}\text { The criterion of a members is everyone who has } \\
\text { been working in Indonesia at least } 6 \text { months, in- } \\
\text { cluding expatriate which receive salary, wage, or } \\
\text { other reward }\end{array}$ & \\
\hline & & $\begin{array}{l}\text { The portion of payment is regulated by Ministry } \\
\text { of Labors periodically which is in the year } 2015 \\
\text { the payment for the low income household is paid } \\
\text { by the Government; while for the employees it is } \\
5 \% \text { per household where } 1 \% \text { paid by employees } \\
\text { and the rest of it paid by employers }\end{array}$ & \\
\hline \multirow[t]{3}{*}{7} & \multirow[t]{3}{*}{$\begin{array}{l}\text { Law No. } 41 \text { of } \\
2004 \text { regarding } \\
\text { Waqaf }\end{array}$} & $\begin{array}{l}\text { Waqaf is a legal action to separate and/or deliver } \\
\text { part of someone's property for the religious pur- } \\
\text { pose and/or public welfare either for certain peri- } \\
\text { odic of time or forever according to Islamic } \\
\text { syari'a }\end{array}$ & \multirow[t]{3}{*}{$\begin{array}{l}\text { Waqif for reli- } \\
\text { gious and/or } \\
\text { public welfare } \\
\text { on voluntary } \\
\text { based }\end{array}$} \\
\hline & & $\begin{array}{l}\text { In order to assure waqaf's goal and function, the } \\
\text { allocation of it should only for a) Islamic worship } \\
\text { facility, b) education and health facility and activ- } \\
\text { ity, c) supporting the poor, abandon children, } \\
\text { scholarship, d) enhancing and increasing econ- } \\
\text { omy ummah and/or improving other public's wel- } \\
\text { fare which is not contradictory with syari'a and } \\
\text { regulations }\end{array}$ & \\
\hline & & $\begin{array}{l}\text { Nazhir as a party that has a right to manage such } \\
\text { action as syari'a regulation, should administered, } \\
\text { managed, supervised, and reported the waqaf } \\
\text { rightly and should have a right for it maximum } \\
10 \% \text { of given waqaf }\end{array}$ & \\
\hline \multirow[t]{2}{*}{8} & \multirow[t]{2}{*}{$\begin{array}{l}\text { Law No. } 16 \text { of } \\
2001 \text { regarding } \\
\text { Foundation } \\
\text { which is } \\
\text { amended with } \\
\text { Laws No. } 28 \\
\text { of } 2004\end{array}$} & $\begin{array}{l}\text { Foundations could be established to participate in } \\
\text { supporting social, religious, and humanity activity } \\
\text { through separating wealth (cash or goods) with no } \\
\text { members involved. Therefore, the activity is focus } \\
\text { only to maximize the wealth accumulated from } \\
\text { donor and other activities for the foundation pur- } \\
\text { poses }\end{array}$ & \multirow[t]{2}{*}{$\begin{array}{l}\text { Everyone for } \\
\text { social, religious, } \\
\text { and humanity } \\
\text { on voluntary } \\
\text { based. }\end{array}$} \\
\hline & & $\begin{array}{l}\text { The wealth of the foundations is forbidden to } \\
\text { transfer or divide to founders, managers, supervi- } \\
\text { sors, employees, or other concern party in the } \\
\text { form of salary, wage, honorarium, or other form } \\
\text { that can be valued financially either directly or } \\
\text { indirectly }\end{array}$ & \\
\hline
\end{tabular}

From the discussion above, it is noted that the approach of the regulations related to philanthropy mostly is obligation not voluntary; only 3 of them that put a voluntary principle inside those laws. This means that regulation has a limitative authority to accommodate the voluntary activities of members of society par- ticipated into development agenda since it is voluntary. However, if the government has clear and focus program for the philanthropist to fulfil in the term of development activities, the effectiveness of the philanthropist actions can be benefit greatly to the society. 
Housing is one of the priorities of development activity in Indonesia; when people have a descent and sufficient house, the member of the family could grow properly so they can handle any obstacle they face more effectively. This is a notion of putting housing is priority for Indonesian better life as stated in the Constitution. From 8 regulations mentioned above, it is possible to energize philanthropy actions for provide access for low income households for housing; only Law No. 13 of 2011 regarding Poor Household Management that focus only for foods and clothes for the poor. This means that if the government makes a clear and focus program for housing for low income households integrated to SDGs, Indonesia Development Plan, and philanthropy activities, the better environment for further development could be achieved.

\section{Hypothesis}

The hypothesis of this research are:

1. Regulations have not give adequate measurement to stimulate low income household in accessing sufficient house in Indonesia;

2. Various regulations have substance of encouraging rich people in Indonesia doing philanthropy activities, however such activities still sporadic and disperse so that the impact of the activities very much depends on those philanthropists merely;

3. Using accumulation method, it is possible to make greater impact of philanthropy activities in Indonesia for better Indonesian people life, especially for accessing sufficient house for low income household;

4. To be able to access sufficient house for low income households could make a significant change for their life and better future for their children, so that poverty circle can be cut off.

\section{ANALYSIS AND DISCUSSION The Direction of Housing Policy in Indonesia}

One of the problems in improving the welfare of employers in Indonesia is ability to have decent and affordable house. Since the minimum salary of employers here by regulation only refers to minimum life needs that obviously not covering accessibility to the house. On the other hand, the price of house or property in general is increasing every year. It seems that if there is no intervention whatsoever, employers never able to have house for their rest of life.

Understanding that home as a center of family to grow, develop, and improve socially, spiritually, and even economically, it is important for Indonesian people to have a decent house to develop and get a better life. However, no everyone can afford it, while the Government of Indonesia has no resources to provide the house for everyone. Other alternatives invite and involve every components of society to participate actively and purposely in this matter. One of the idea is to channeling the CSR in supporting affordability of law income household in general, and employers specifically, to have a decent house. 
Although housing is recognized as one of basic human needs in Indonesia as reflected in three basic humans: sandang, pangan, papan (cloth, food, house); but in the policy level, it is not yet as an urgent as the other two basic needs. Housing is still considered as secondary or even luxurious goods that very much depend on market. There is no policy or program from the Government to promote and accelerate the ability of people to have housing here until the year 2011 when Law Number 1 of 2011 passed by parliament. According to the new Law, it is the Government duty to enhance and increase the ability of the Indonesian people to access house through providing decent and affordable house for all gradually until 2014. However, the data shows that the need of the house increases every year due to the growth of people which is not in line with the provision of house for them. In 2004, the backlog is only 5.8 million unit of house but the number doubled in 5 years became 7.4 million unit of house in 2009 . If the trends still takes place, it is estimated that the backlog in 2014 will be 12 million unit of house ${ }^{2}$.

The idea to promote to access a quality house for everyone is that the house is not only considered as a shelter merely today. A house could be a center of capacity building of people who live in it. When people have a quality house, they have an opportunity to develop themselves toward a better life. This is

${ }^{2}$ Asosiasi Perumahan Nasional (Apersi), Optimalisasi dan Sinergitas Mitra Kerja untuk Menyukseskan Pembangunan Perumahan MBE,2011. the idea behind the Law No. 1 Year 2011 of Housing.

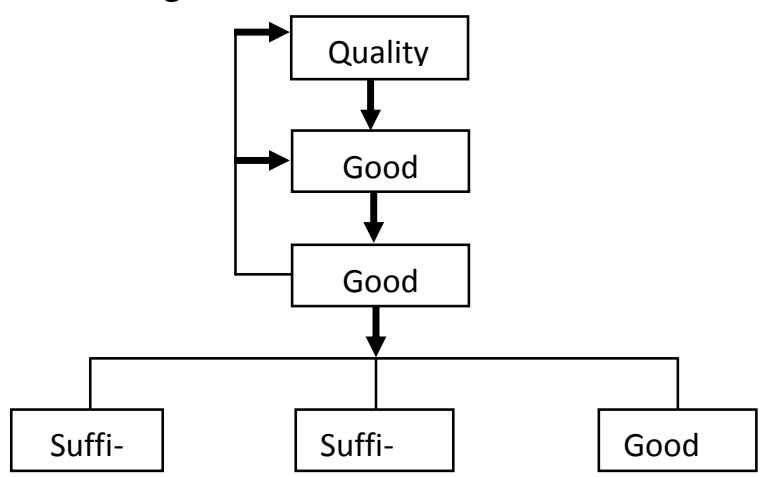

Figure 1. Policy Framework of Housing and Residential Management

Therefore, it is essential to provide a quality house for everyone. For those who can't afford one, it is a Government task to think formulae to give those unfortunate community members to access the quality house. In policy level, the notion of providing house for the people of Indonesia, especially for low income household aims to increasing the welfare of the people. However, the technical measurement of achieving the notion mentioned above has not well explained either in policies and regulations related. Therefore, it is needed to formulate the mechanism to fill the gap; and the most probable and applicable measurement is mechanism that embodied in related regulations which forcible in practice.

\section{Implementation of Philanthropy Policy in Indonesia}

There is no official data to show how much philanthropy Indonesia. However, from some non-government organization that concern with humanity we can assume that no more than 50 organizations involved in this issue. 
Philanthropy Indonesia is an organization that accommodate and facilitate philanthropy organization in Indonesia says that they have 40 organizations and 54 individual members around Indonesia. The focus of the organization activity is to increase the quantity and quality of philanthropy within and for Indonesia, and to strengthen civil society in the country, by empowering the institutional infrastructure and expanding the space for philanthropy and the non-profit sector.

In the year 2014, Philanthropy Indonesia was able to gather fund accumulated from donator and other resources as much as 12,5 trillion rupiahs and the number still not much if we compare to fund raised in USA from Indonesia expatriate which is about US\$ 3 million in the same year. This fact tells us that the potential of gathering fund from philanthropist is huge. The collected fund has been distributing to the society through several programs such as social assistance, natural disasters, start-up business, art, culture, and others ${ }^{3}$.

In order to have a clear picture how philanthropy works in Indonesia we can see from specific organization that dedicated its activity for this purpose such as
Badan Amil Zakat Indonesia (Indonesia Zakat Organization) or BAZNAS. As described above, zakat is certain amount of money that should be paid by Muslims when they have property that achieved qualified calculation according to sharia to other member society that in need. This activity is not obligation in the sense that if a Muslim did not pay his/her zakat, the government then punished him/her. The decision of paying the zakat or not is absolutely Muslims' choice; the effect of it only in religious area. BAZNAS help Muslims to calculate zakat and distribute them to qualified receivers.

From its report in the year 2015 we can see how the flow of zakat from the giver to receiver. The amount zakat that accumulated around 3 trillion rupiahs, while the distribution to the society around 2,2 trillion rupiahs which is $61,6 \%$ of the accumulated zakat has been distributed to the society.

The trend is increasing every year since the year 2002 as seen in Table 2, the growth is around 5\% every year. When we look into area of distributions of $z a$ kat, we can see the spent of zakat to each area as shown in Table 3.

Table 2: The Collection and Distribution of Zakat

\begin{tabular}{|c|c|c|c|c|c|}
\hline \multirow{2}{*}{ Instansi } & \multicolumn{2}{|l|}{ Pengumpulan } & \multicolumn{2}{|l|}{ Penyaluran } & \multirow{2}{*}{ Daya Serap } \\
\hline & $\mathbf{R p}$ & $\%$ & Rp & $\%$ & \\
\hline BAZNAS & $94,068,893,820$ & 2.58 & $66,766,033,369$ & 2.97 & \multirow{4}{*}{$61,6 \%$} \\
\hline BAZNAS Provinsi & $642,797,514,841$ & 17.61 & $342,123,210,249$ & 15.21 & \\
\hline BAZNAS Kab/Kota & $885,309,169,850$ & 24.25 & $578,140,590,276$ & 25.70 & \\
\hline LAZ & $2,028,193,434,453$ & 55.56 & $1,262,130,957,632$ & 56.12 & \\
\hline Total & $3,650,369,012,964$ & 100.00 & $2,249,160,791,526$ & 100.00 & Cukup Efektif $^{1}$ \\
\hline
\end{tabular}

${ }^{3}$ http://www.cnnindonesia.com/teknologi/2016110

7155412-185-170940/kaum-dermawan-mulailirik-startup/ [retrieved: September 21, 2017]. 
Table 3: The Zakat Accumulation Trend 2002-2019

\begin{tabular}{|c|r|c|c|l|}
\hline Tahun & $\begin{array}{c}\text { ZIS } \\
\text { (Milyar Rp) }\end{array}$ & $\begin{array}{c}\text { Pertumbuhan } \\
(\%)\end{array}$ & $\begin{array}{c}\text { Pertumbuhan } \\
\text { PDB (\%) }\end{array}$ & \multicolumn{1}{|l|}{ Catatan } \\
\hline 2002 & 68.39 & 0 & 3.70 & \\
\hline 2003 & 85.28 & 24.70 & 4.10 & \\
\hline 2004 & 150.09 & 76.00 & 5.10 & Tsunami Aceh \\
\hline 2005 & 295.52 & 96.90 & 5.70 & \\
\hline 2006 & 373.17 & 26.28 & 5.50 & \\
\hline 2007 & 740.00 & 98.30 & 6.30 & Gempa Yogya \\
\hline 2008 & 920.00 & 24.32 & 6.20 & \\
\hline 2009 & 1.200 .00 & 30.43 & 4.90 & \\
\hline 2010 & 1.500 .00 & 25.00 & 6.10 & \\
\hline 2011 & 1.729 .00 & 15.27 & 6.50 & \\
\hline 2012 & 2.212 .00 & 27.94 & 6.23 & \\
\hline 2013 & 2.639 .00 & 19.30 & 5.78 & \\
\hline 2014 & 3.300 .00 & 25.05 & 5.02 & \\
\hline 2015 & 3.650 .00 & 10.62 & 4.79 & \\
\hline \multicolumn{2}{|r|}{ Rerata } & $\mathbf{3 5 . 7 2}$ & $\mathbf{5 . 4 2}$ & \\
\hline
\end{tabular}

Table 4: Zakat Distribution For Each Ashnaf

\begin{tabular}{|r|l|r|r|r|r|}
\hline \multirow{2}{*}{ No Ashnaf } & \multicolumn{2}{c|}{ Penyaluran } & \multicolumn{2}{c|}{ Penerima Manfaat } \\
\cline { 3 - 6 } & & Jumlah Dana & \multicolumn{1}{c|}{$\%$} & Jumlah Jiwa & \multicolumn{1}{c|}{$\%$} \\
\hline 1 & Fakir Miskin & $1,519,501,961,720$ & 67.56 & $4,393,279$ & 86.48 \\
\hline 2 & Amil & $200,830,665,378$ & 8.93 & 10,326 & 0.20 \\
\hline 3 & Muallaf & $19,094,327,558$ & 0.85 & 14,343 & 0.28 \\
\hline 4 & Rigob & $10,569,125,452$ & 0.47 & 826 & 0.02 \\
\hline 5 & Gharimin & $13,282,379,774$ & 0.59 & 6,843 & 0.13 \\
\hline 6 & Fi Sabilillah & $462,451,321,660$ & 20.56 & 632,536 & 12.45 \\
\hline 7 & Ibnu Sabil & $23,431,009,983$ & 1.04 & 21,758 & 0.43 \\
\hline \multicolumn{2}{r|}{ Total } & $\mathbf{2 , 2 4 9 , 1 6 0 , 7 9 1 , 5 2 6}$ & $\mathbf{1 0 0 . 0 0}$ & $\mathbf{5 , 0 7 9 , 9 1 1}$ & $\mathbf{1 0 0 . 0 0}$ \\
\hline
\end{tabular}

Ashnaf means people that have a right to receive zakat, i.e. poor people, zakat administrator, people who convert his believe into Islam, people in travelling, and people who manage his life for Allah such as getting better education either religious or general. From the data above we can see that most of zakat distribution goes to poor people that take around $67 \%$ of all zakat distribution with more than 4 million people as receivers. The next area is the group that trying to achieve a better life through scholarship which takes $20,5 \%$ of zakat distribution with more than six hundred thousand people involved.

The fund raising from philanthropy activities in Indonesia is relative big; since the population number that more than 210 million people added by the norm and religious that they have, the potent of philanthropy is huge. Unlike philanthropy in other country where philanthropist is rich people, Indonesian with average income could also become philanthropist as Islam as the religion of majority of Indonesian people ask them to give a zakat or infaq or charity periodically as a symbol of grateful attitude toward Allah.

The other philanthropic activity for housing as conducted by Rumah Zakat ${ }^{4}$.

\footnotetext{
${ }^{4}$ Rumah zakat is an organization of collecting and gathering zakat or alms from muslim as their obligation toward their property. The Qur'an said that every muslim that has earned more than their
} 
Although Rumah Zakat is not focus only for providing housing for the poor, however some of their activity also touch to the issue. Rumah Zakat has built what so called Desa Berdaya (Empowering Village) which is a program for empowering the village through education, health, economy, and environment including rehabilitate house according to each village needs. Until 2016, there are around 800 villages have been empowering and involved more than 1,4 million of people ${ }^{5}$.

\section{The Challenge of Philanthropy for Housing}

From legal perspective, the obligation of provide housing for low income household is in the Government. However, the financial ability of the Government is limited so that the Government should seek the alternative to invite business sector for it which is to oblige developers to provide housing for the low income households when they build commercial housing. The other reason is to create inclusive housing environment where there is no boundary for the rich and poor people. $^{6}$

To overcome the Government shortage for providing the housing could be done by using corporate responsibility (CSR) for its environment known as corporate social responsibility. According to Archie B. Caroll, the CSR is in a top of corporate responsibility pyramid.

needs (wealth) they obliged to pay zakat $2,5 \%$ of their property yearly as their contribution for the poor in the society.

${ }^{5}$ http://filantropi.or.id/berita/d/rumah-zakat-

bangun-1080-desa-berdaya-di-indonesia,

[retrieved: May 21, 2017].

${ }^{6}$ The Law No. 1 of 2011 Regarding Housing and Resident Management.

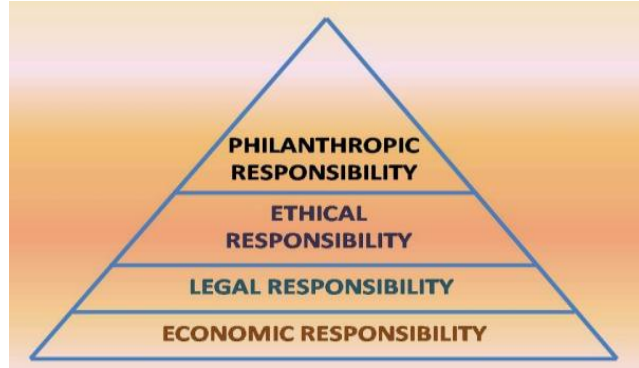

Figure 2: Responsibility Pyramid of Corporation

Ideally, a corporate is not only focus on its economic responsibility as it is in the bottom of its responsibility in Caroll's pyramid. It is understood that the primary goal of a corporate is to make a profit. Profit is a foundation of the company in order to survive. At the second level, the corporate has legal responsibility, this means that the corporate should obey the law. Although the corporate is focus in profit making, but it is not allowed to infringe the law in the process rather it should obey and follow the law. On the third level is ethical responsibility which means that the corporate should have ethical perspective in doing their business i.e. sense of good, fair, and just business practice along with community norms as a corporate organization behavior's guideline. At the top the pyramid as also shows the importance of the matter is philanthropic responsibility as a representative of being a good citizen. The corporate besides attempts to get profit, obey the law, and behave ethically, it is also required to make a contribution to the society as a part of its role as a citizen. The aim of this is to increase the quality of life of all; in this notion CSR is embedded. Therefore, CSR could be seen as 
philanthropic responsibility of the corporate $^{7}$.

Although the Law No. 40 of 2007 Concerning Limited Liability Corporation especially in Article 74 states that corporation which involves in and/or relates to natural resources obliges to conduct social and environmental responsibility, and highlighted that this obligation must be allocated and financed as a corporate expense which must be conducted in rational and normal way; however, the implementation of CSR by corporations had not stipulated specifically. The interpretation to that is as long as it concerns social matters, the corporations could do this as wide as the interpretation could be. According to the research in 2004, corporations tend to use their CSR in 8 social activities:

\section{Table 5: Corporations' CSR Activities}

\begin{tabular}{|c|c|c|}
\hline Activities & Amount & Budget \\
\hline Social services & $\begin{array}{c}95 \text { activities } \\
(34.1 \%)\end{array}$ & $\begin{array}{c}38 \mathrm{M} \\
(33.0 \%)\end{array}$ \\
\hline $\begin{array}{l}\text { Education and } \\
\text { research }\end{array}$ & $\begin{array}{c}71 \text { activities } \\
(25.4 \%)\end{array}$ & $\begin{array}{c}66.8 \mathrm{M} \\
(57.9 \%)\end{array}$ \\
\hline Health & $\begin{array}{c}46 \text { activities } \\
(16.4 \%)\end{array}$ & $\begin{array}{l}4.4 \mathrm{M} \\
(3.8 \%)\end{array}$ \\
\hline Emergency & $\begin{array}{c}30 \text { activities } \\
(10.8 \%)\end{array}$ & $\begin{array}{l}2.9 \mathrm{M} \\
(2.5 \%)\end{array}$ \\
\hline Environment & $\begin{array}{c}15 \text { activities } \\
(5.4 \%)\end{array}$ & $\begin{array}{l}395 \mathrm{Jt} \\
(0.3 \%) \\
\end{array}$ \\
\hline $\begin{array}{l}\text { Economy pro- } \\
\text { ductive }\end{array}$ & $\begin{array}{c}10 \text { activities } \\
(3.6 \%)\end{array}$ & $\begin{array}{l}640 \mathrm{jt} \\
(0.6 \%)\end{array}$ \\
\hline $\begin{array}{l}\text { Art, sport, } \\
\text { tourism }\end{array}$ & $\begin{array}{c}7 \text { activities } \\
(2.5 \%)\end{array}$ & $\begin{array}{c}1.0 \mathrm{M} \\
(0.9 \%)\end{array}$ \\
\hline $\begin{array}{l}\text { Housing facili- } \\
\text { ties }\end{array}$ & $\begin{array}{c}5 \text { activities } \\
(1.8 \%)\end{array}$ & $\begin{array}{c}1.3 \mathrm{M} \\
(1.0 \%)\end{array}$ \\
\hline $\begin{array}{l}\text { Law, advo- } \\
\text { cacy, politic }\end{array}$ & 0 & 0 \\
\hline TOTAL & 279 activities & $115.3 \mathrm{M}$ \\
\hline $\begin{array}{ll}\text { Source: } & \text { Saidi a } \\
& \text { Social } \\
& \text { Develo }\end{array}$ & $\begin{array}{l}\text { Abidin (2004) } \\
\text { ork, CSR and } \\
\text { ent }\end{array}$ & $\begin{array}{l}\text { in Suharto, } \\
\text { Community }\end{array}$ \\
\hline
\end{tabular}

${ }^{7}$ Ardianto, E. \& Machfudz, D. (2011). Efek Kedermawanan Pebisnis dan CSR. Jakarta: PT Elex Media Komputindo.
The data shows that the biggest amount of CSR went to education and research activities that involve $\mathrm{Rp} 66.8$ milliard. This suggest that corporations still consider that education and research sectors become the most important social problems that they willing to involve. Only 5 activities that suggest some of corporations have already the attention to housing sector, although they concerned to provide housing facilities, not the access or purchase the house for low income household itself. One of this activity as shown in the study in 2010 (Musrifah, 2010) shows that PT Aneka Tambang Tbk conducted CSR in Nanggung Resident - Bogor in housing sector. The scope of the program from rehabilitate house and fund for rehabilitate house into descent and qualified house.

The potential of using philanthropic approach for providing housing for poor people is great. The study in 2011 shows this significant potential. Using 59 corporates reports (state enterprises, national and international private business entities) representing important industry sector in their annual report and sustainability report, the data shown that the profit of the corporates is increasing from 971 trillion in 2009 to 1,585 trillion in 2011. This effects to their CSR which must be allocated as in their operational budget. Although not all of respondents give their answer to how much money they allocated for the CSR, the proportion of CSR of the 59 corporates could be seen as below: 16 corporates: $1,6 \%$ from the profit; State Enterprises: 2,7\% from the profit; Private Business Entity: 0,53\% from the profit. 
From the trend above the rate of CSR allocated is around 1,5\% from the profit. If we put this to the 59 corporates above could reach more than 16 trillion.

\section{Figure 3: The Trend of CSR from}

2009-2011

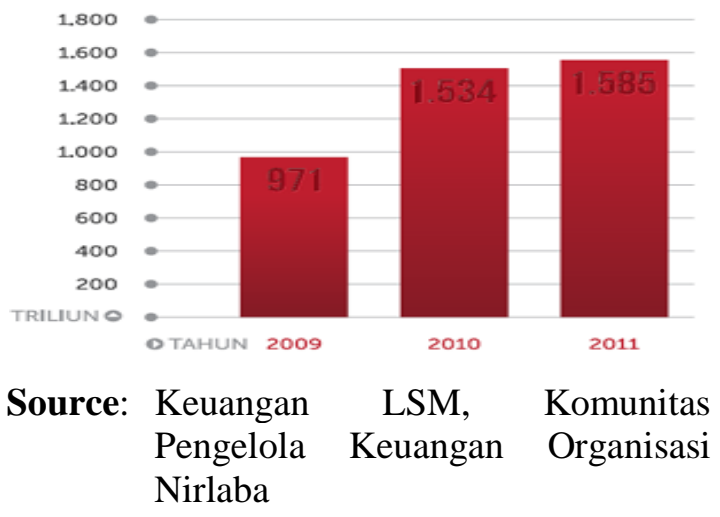

The increasing trend as shown above has significant economic value for using as CSR, including for housing.

Using philanthropy for housing including CSR in it aims to support the lower income household as priority according to the Law No. 1 of 2012 regarding Housing. Realizing that the law income household has a limited access to have a decent house; the mission of the Government then supports them in many ways to be able to have a house. This important task is done by facilitating the provision of houses for the group. The facility focuses on creating a funding scheme that makes the group could participate actively in house market.

There are two ways for the Government to enhance the ability of law income household to have a house: a) providing public housing either for rent or for sale; b) facilitating provision of house for the group.

The Government has several programs have been set up to enhance the ability of accessing house for poor peo- ple. One of them is the program of facilitating housing fund liquidity coordinated by Ministry of Housing that launched in the year 2012. Through this program the Government provides fund that blended with bank's housing commercial fund that could make lower housing budget for the low income household in turn. In order to support this program, Ministry of Finance also passed the Ministry of Finance Regulation No. 125/PMK.011/2012 concerning Added Value Tax Waver for certain type of houses.

After the two regulations were taken place, the implementation of the policy above still far from the Government's expectancy though. According to Ministry of Housing, in the year 2012 the result of the program only 62.055 unit; this is only half from the Government's target which is 133.000 houses' unit that used 2.45 trillion rupiahs and involved 21 banks.

Table 6: House Unit for Low Income Household through Banking System

\begin{tabular}{lll}
\hline \multicolumn{1}{c}{ Bank } & House's unit & $\begin{array}{c}\text { Amount } \\
\text { (Rupiahs) }\end{array}$ \\
\hline BTN & 57.885 & 2,29 Trillion \\
\hline BTN Syariah & 2.746 & 107 Billion \\
\hline Others & $100-600$ & 153 Billion \\
\hline
\end{tabular}

The main problem to the unsuccessful program is the limited ability of the bank in channeling the fund to low income household. This also indicates that the program push banks to seek prospective consumers that fit to the program's requirement; not only waiting in their office for low income household to come. ${ }^{8}$

\footnotetext{
${ }^{8}$ Lubis, Efridani, 2015. Supporting Low Income Household to Access a Sufficient House Through
} 
The definition of law income household itself is not matched with the reality of the group that needed the support most. According to Ministry of Housing Regulation No. 05/Permen/M/2007 the income indicator refers to low is people with income maximum 2.500.000 rupiahs per month. The same amount is recognized by the new regulation, Ministry of Housing Regulation No. 14 Year 2010. Interestingly, when the Ministry of Housing amended the last regulation with Ministry of Housing Regulation No. 04 Year 2012, the new approach had been made to the issue. As a target of Housing Facility of Housing Fund Liquidity (FLPP), the low income household divided into two categories:

1. For land houses, the definition of low income household is people with maximum income 3.500.000 rupiahs;

2. For apartment or flat, the definition of low income house-hold is people with maximum income 5.500 .000 rupiahs.

The changed criteria above effected into two levels: first, it seems that the criteria of low income household has not been set definitively, since the target of the people that could get subsided from the Government only based on their income merely which tends to increase over time. Second, the notion of providing shelters built up on the top of another like apartment or flat is to minimize the operation cost that could impacted to the lower price of the house significantly so that low income household could afford

Corporate Social Responsibility (CSR) as a Mechanism for Enhancing Low Income Household in Accessing a Quality Affordable House, Proceeding, Universitas Brawijaya. the house. However, the regulation above views the notion differently; the apartment or flat's price defines more expensive than land house, so that income requirement that subsided by the Government higher than income requirement for land house. ${ }^{9}$

From the explanation above the main issue of facilitating housing for low income household is how to make channeling housing fund from the Government and business entities effective and efficient. In this sense, doing such channeling needs some supporting elements that could make the facilitating program will be success. These elements at least covering: ${ }^{10}$

1. Fund raised from CSR for housing should be in the form of trust fund which could be developed by fund manager productively. The idea is to develop CSR fund more productive so that could be covers more people.

2. Special and independent institution to manage and to take responsible in guarantee that low income household appointed will be able to access the house.

At this point, the scheme could use the existence of Forum for Community Development (CFCD). This organization was established by corporate that commit to perform CSR effectively and efficiently. The other issue that must be considered is to reach the most prospective member community. In this sense, it is necessary to set up procedure that can be used to select the potential user of CSR for housing sector. According to Parahyangan University Team there are five

\footnotetext{
${ }^{9}$ Note 8 .

${ }^{10}$ Note 8 .
} 
elements should be considered when formulating the effective CSR mechanism:

1. Engagement: it is necessary to make initial movement toward commu-nity in order to establish good communication and relation. This step could also be used as insemination of the program therefore people understand and accept the program. The main goal of this step to build trust among stakeholders that can be considered as social capital which can be used as social contract between communities and involved corporate.

2. Assessment: problem and need identification that will be used as a basic consideration in formulating the program. This step is not only could be done using needs based approach but also can use right-based approach.

3. Plan of action: the program will be applied must also take into account the stakeholders aspiration on one hand and at the same time also consider corporate mission including shareholders interest on the other hand.

4. Action and facilitation: the program could be performed by community directly and independently, but could also be facilitated by corporate or NGO. Monitoring, supervision and mentoring are the key of succeed program implementation.

5. Evaluation and termination or reformation: using this mechanism to develop better program in the future. If evaluation shows the program must be ended (terminated) then necessary document or contract should be provided including exit strategy between involved parties. But if the program could be continued (reformatted) then it is essential to draw up lesson learnt for developing next CSR program.

The use of all approach above, Philanthropy for Housing could be formulated as describe below.

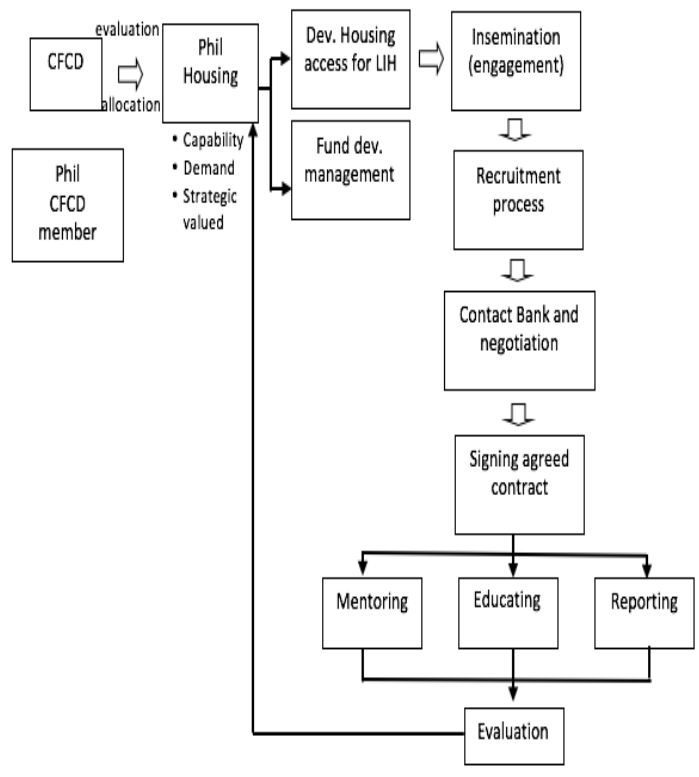

Figure 4: Philanthropy for Housing Scheme $^{11}$

\section{CONCLUSION}

Providing a house for all as Government obligation constitutionally is not an easy task. The main obstacle to do that is the limitation of Government budget for housing; since there are many areas that more important that need Government financial support such as education and health; and this makes housing sector become less urgent. However, the need of house for all becomes more critical because some experts believe that the center of good and strategic developing the society begins with family in descent

\footnotetext{
${ }^{11}$ Adapted from Lubis, Note 8.
} 
house; this means that people can achieve good education and health from good house environment.

In order to get decent and affordable house for low income household, the main issue is financial support for them to access the good house. Although this is a part of the Government obligation according to constitution and related regulations, but since there are many other priorities that considered more urgent than housing, so the financial support also is given to those priorities; while housing is considered a strategic instrument to get a better life. An alternative to this situation could be maximized the philanthropy obligation of the corporations through CSR to fulfill the financial gap for housing. However, to make sure the scheme could be done effectively it requires several elements needed, including Forum for Community Development as a forum to collect and gather the philanthropy from private business sector.

\section{Key Findings}

In order to support low income households to access sufficient house using implementation of philanthropy related regulations, there are some key findings factors:

1. Form 8 regulations relate to philanthropy activities in Indonesia, there is a possibility of maximizing those activities toward supporting low income household for accessing sufficient house. Combination of facilities provided by the Government and financial or other resources from philanthropists makes the possibility of low income households for accessing sufficient house increase.

2. In order implement the idea mentioned above, certain institution that gathering and organized the collected resources for housing for low income households is needed. The institution could be inside Forum for Community Development (CFCD) that gathering CSR from companies in general or could be a specific institution that consist of representative of philanthropists, the Government, community, and developers.

3. To make the method effective, it is necessary to have significant and valid database of low income households nationally so that the schedule of each household could access the house is certain and accountable.

\section{RECOMMEDATION}

1. The Ministry of Public Works and Housing of the Government of Indonesia could facilitate of establishing the institution that gathering and organizing the resources from philanthropist and the Government for accessing sufficient house for low income households. This is a part of the Ministry tasks that stipulated in Law No. 1 of 2012 regarding Housing.

2. The Ministry of Public Works and Housing of the Government of Indonesia could provide data base of low income house updated every year which is accessible to all.

It is essential to make technical regulation in 'ministry regulation' level to make the mechanism of accessing house for low 
income households possible and conduct in effective and efficient way

\section{REFERENCES}

Asosiasi Perumahan Nasional (Apersi). 2011. Optimalisasi dan Sinergitas Mitra Kerja untuk Menyukseskan Pembangunan Perumahan MBE.

Brilliant, Eleanor L. dan Kimberlee A. Rice. 1988. "Influencing Corporate Philantropy" in Gary M. Gould dan Michael L. Smith (eds), Social Work in the Workplace, New York: Springer Publishing Co.

Castka, Pavel, 2005. Chris Bamber, and John M Sharp. Implementing Effective Corporate Social Responsibility and Corporate Governance, A framework. British Standards Institution and the High Performance Organisation Ltd.

Frederick, W. 2006. Corporation, Be Good! The Story of Corporate Social Responsibility. Indianapolis: Dog Ear Publishing.

Hadi, Nor. 2011. Corporate Social Responsibility. Yogyakarta: Graha Ilmu.

Hohnen, Paul, Jason Potts (Ed.). 2007. Corporate Social Responsibility An Implementation Guide for Business, International Institute for Sustainable Development.

Kalangit, Holy K. M. 2009. Konsep Corporate Social Responsibility, Pengaturan dan Pelaksanaannya di Indonesia.

Lubis, Efridani, 2015. Supporting Low Income Household to Access a Sufficient House Through Corporate Social Responsibility (CSR) as a Mechanism for Enhancing Low Income Household in Accessing a Quality Affordable House, Proceeding, Universitas Brawijaya - Malang.

Mazurkiewicz, Piotr. Corporate Environmental Responsibility: Is a Common
CSR Framework Possible?, DevCommSDO, World Bank.

Musrifah. 2010. Penerapan Corporate Social Responsibility (CSR) Bidang Perumahan Pada Wilayah Binaan PT. Aneka Tambang Tbk. di Kecamatan Nanggung Kabupaten Bogor, Tesis, Universitas Dipenogoro.

Porter, Michael E. dan Mark R. Kramer. 2002. "The Competitive Advantage of Corporate Philanthropy", in Harvard Business Review, December.

Rahmatullah. 2011. Panduan Praktis Pengelolaan CSR. Yogyakarta: Samudra Biru.

Roestamy, Martin. 2010. Konsep Hukum Kepemilikan Rumah dan Bangunan Bagi WNA (Dihubungkan dengan Hukum Pertanahan). Bogor: Unida Press.

Saidi, Zaim dan Hamid Abidin. 2004. MenjadiBangsa Pemurah: Wacana dan Praktek Kedermawanan Sosial di Indonesia. Jakarta: Piramedia.

Smith, Richard E. 2011. Defining Corporate Social Responsibility: A Systems Approach For Socially Responsible Capitalism. University of Pennsylvania.

Tanudjaja, Bing Bedjo, Perkembangan Corporate Social Responsibility di Indonesia, Universitas Kristen Petra Surabaya.

Tim Universitas Katolik Parahyangan. Corporate Social Responsibility: Konsep, Regulasi dan Implementasi. 